\title{
Astronomy and Sun Cult in the Swedish Bronze Age
}

\author{
Nils-Axel Mörner ${ }^{*}$, Bob G. Lind ${ }^{2}$ \\ ${ }^{1}$ Paleogeophysics \& Geodynamics, Stockholm, Sweden \\ ${ }^{2}$ Archaeoastronomy, Malmö, Sweden \\ Email: ^morner@pog.nu
}

How to cite this paper: Mörner, N.-A. and Lind, B.G. (2018) Astronomy and Sun Cult in the Swedish Bronze Age. International Journal of Astronomy and Astrophysics, 8, 143-162.

https://doi.org/10.4236/ijaa.2018.82010

Received: February 27, 2018

Accepted: May 6, 2018

Published: May 9, 2018

Copyright (c) 2018 by authors and Scientific Research Publishing Inc. This work is licensed under the Creative Commons Attribution International License (CC BY 4.0).

http://creativecommons.org/licenses/by/4.0/

(c) (i) Open Access

\begin{abstract}
The Scandinavian Bronze Age started quite rapidly at around $1750 \mathrm{BC}$, and is marked by three simultaneous events: 1) importation of bronze from the east Mediterranean region, 2) export of amber from southeast Sweden to the east Mediterranean region, and 3) the carving of pictures of big ships on bedrock and boulders in southern Scandinavia. We take this as evidence of travel and trading by people coming from the east Mediterranean region on big ships via Gibraltar and the North Sea to Scandinavia. At the same time, the Sun cult flourished in southern Sweden and Denmark, as evidenced by monuments perfectly oriented with respect to the Sun's daily and annual motions over the sky (e.g. Ales Stones), rock carvings of solar symbols and in solar alignment, and a number of ritual objects related to the Sun Cult (e.g. The Golden Sky Dome). In this paper, we summarize and update available data, especially the data from Southern Sweden.
\end{abstract}

\section{Keywords}

Swedish Bronze Age, Bronze Import, Amber Export, Rock Carving, Sun Cult, Phalluscult, Ales Stones, The Golden Sky Dome

\section{Introduction}

The Bronze Age has a time-transgressive beginning, ranging from $3300 \mathrm{BC}$ in the Near East and 3200 BC in the Aegean region, by 2100 BC in Great Britain to 1750 BC in Central Europe and Scandinavia (Figure 1). This implies an absence of communications between the Aegean region and Great Britain for 1100 years, and between the Aegean region and Scandinavia for 1450 years [1] [2] [3]. By 2100 BC communications were established between the Aegean region and Great Britain, and we know why: the Mycenaeans and Minoans needed tin for 


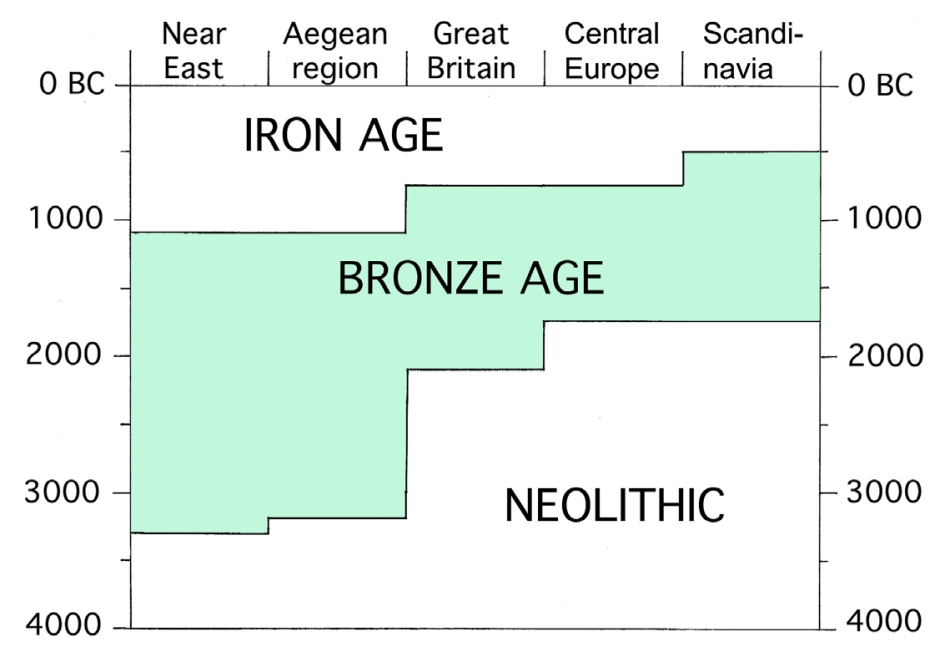

Figure 1. The beginning of the Bronze Age is strongly time-transgressive over the European sector (modified from Mörner \& Lind, 2010) due to the stepwise opening by travel and trading routes between the Aegean region and northwestern Europe. This trading is proposed to have gone via large ships passing Gibraltar and the North Sea.

their bronze production [3] [4] [5]. By $1750 \mathrm{BC}$ the communications between the Aegean region and southern Scandinavia had commenced [1] [2] [3] [6].

Similarly, the Bronze Age ended stepwise; first in the Near East and Aegean region, then in Great Britain and Central Europe, and finally at 500 BC in Scandinavia (Figure 1).

\section{Travel and Trading}

In Scandinavia, the Bronze Age started at $1750 \mathrm{BC}$ and ended by $500 \mathrm{BC}$ (Figure 1 ), and is marked by three simultaneous events (Figure 2):

- The import of bronze.

- The export of amber.

- The rock-carving of huge ships.

We found this time-coincidence striking and natural for a combined theory on the cause of the onset of the Scandinavian Bronze Age:

- People from the Eastern Mediterranean came to Scandinavia in big ships via The Strait of Gibraltar and the North Sea.

- The ships were loaded with bronze.

- They set up a trading station in southeast Sweden.

- They brought back amber, which flooded the Mycenae tombs from about 1600 - 1500 BC.

This theory was first presented at the 33rd International Geological Congress in Oslo [7] and, by invitation, at a meeting in Athens, followed up by a full paper [1], later expanded in subsequent papers [2] [3] [6].

It seems significant that the isotopic composition of the copper in bronze objects found in Sweden all indicate a Mediterranean provenance [8] [9]. This is consistent with long-distance travel and trading. 


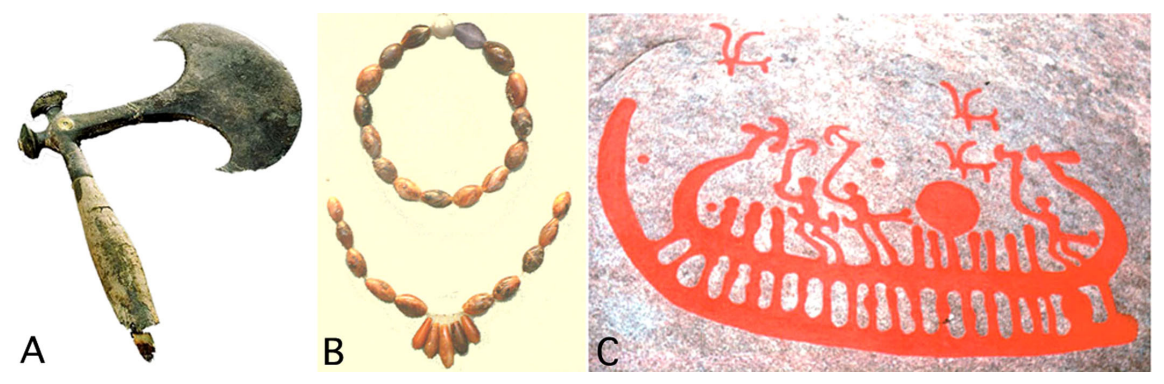

Figure 2. At about $1750 \mathrm{BC}$ three things happened at the same time: Bronze from the Mediterranean appeared in Scandinavia (A); amber from the Baltic (probably from the Ravlunda area) started to appear in masses in Mycenae tombs (B); and pictures of huge ships started to be cut into the bedrock and bronze objects in Scandinavia (C). We interpret this as evidence of active trading and travel with big ships over the Atlantic from Mycenae in Greece to Tanum (SW Sweden) and Österlen (SE Sweden) with the establishment of a trading centre in southeast Sweden [1] [2] [6] [7].

\section{A trading Center}

In the Ravlunda area (Figure 3), amber was accessible in large quantities; partly washed ashore, partly transported by the River Verkeån, and partly out-cropping in the riverbank [1]. The amber found in Mycenaean graves from $1600 \mathrm{BC}$ onwards has a provenance from the Baltic region. Judging from the massive occurrence of amber in the Aegean region, there must have been an extensive import already in the earliest Bronze Age of Scandinavia, giving evidence of active long-distance travel and trading [1] [6].

We therefore proposed [1] [2] [3] [7] [10] that traders from the Aegean region traveling in huge ships over the east Atlantic came all the way up to southern Scandinavia and established a trading center in the Ravlunda-Vitemölla-Kivik area. We expanded on the local setting and possible landing place in [6].

The Kivik grave [11] is located $80 \mathrm{~m}$ from the former shore during the Bronze Age (Figure 4) in the region of Ravlunda-Vitemölla-Kivik proposed as a trading center [1] [2] [3] [6] [7] [10]. The central tomb consists of 8 sepulchral stones decorated on their inner sides. The pictures on those stones are very interesting because they include signs and symbols that seem to indicate their origin from the Aegean region. This was noted by Sven Nilsson, who proposed that they were made by Phoenician traders [12]. We agree in an origin from the Aegean region but add that it must have occurred already at the onset of the Scandinavian Bronze Age by Mycenaean-Minoan people.

We have discussed the motifs on the stones and other symbols of foreign origin in southeast Sweden before [3], and here we will confine our description to the two stones in Figure 4.

In the center of the left stone, 8 birdlike persons seem to be in mourning at the sides of a sarcophagus. It might perhaps be interpreted as the nymphs (heliades) mourning the death of Phaeton, who fell into River Eridanos and died, and where the tears of the nymphs transformed into amber [1]. A possible analogy with the amber found in the River Verkeån was therefore proposed by us. 


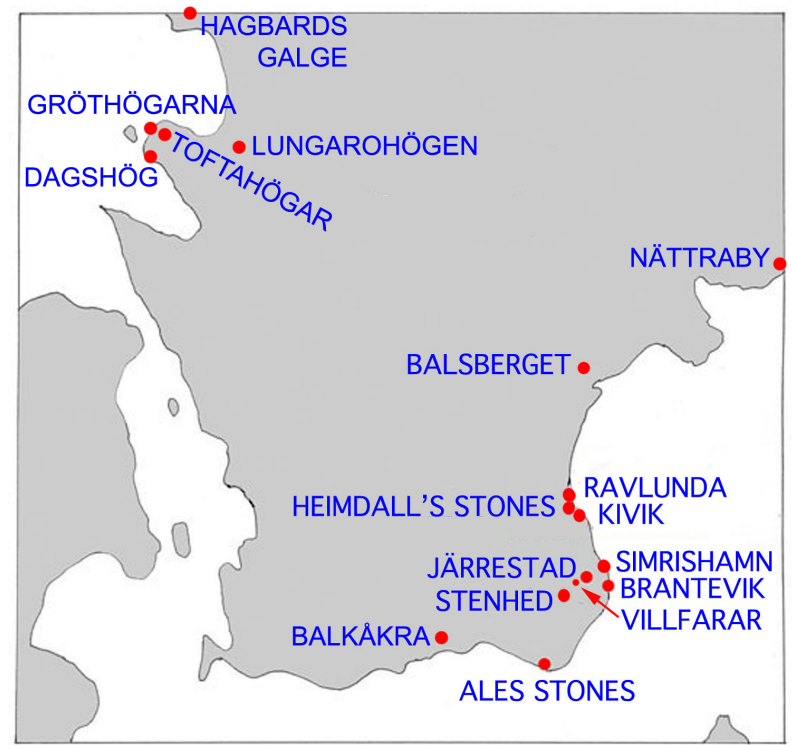

Figure 3. Location of sites in Southern Sweden discussed in the text.

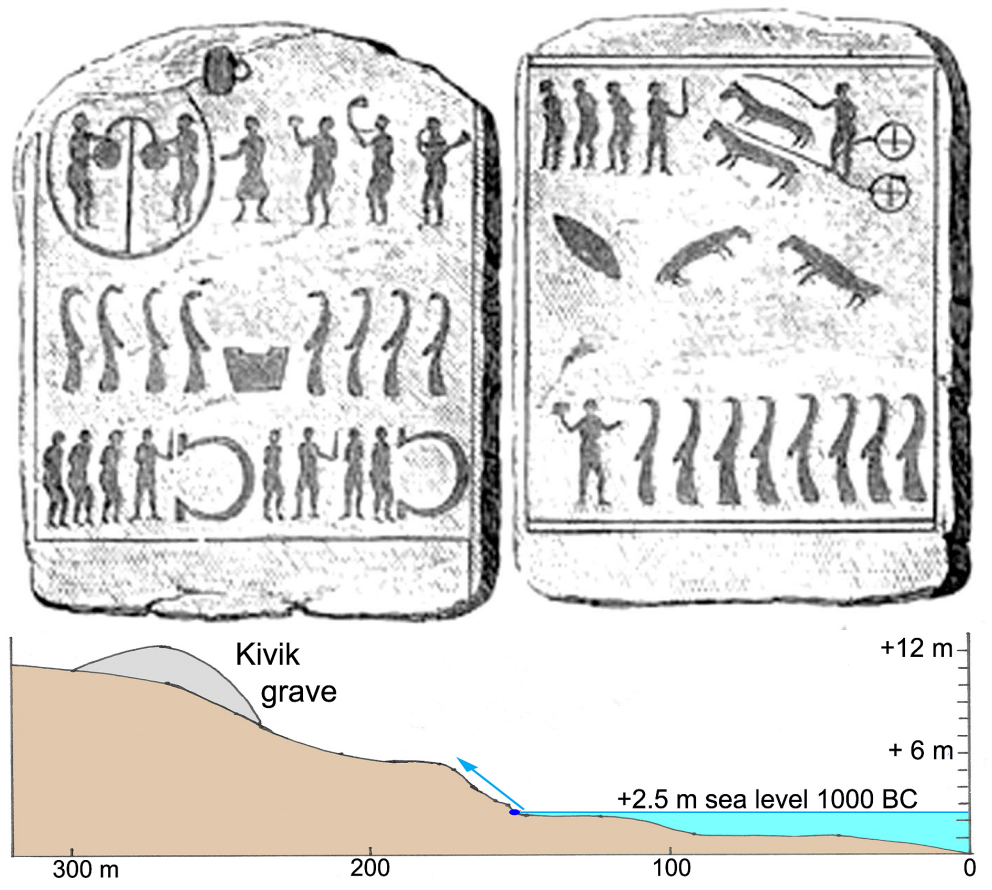

Figure 4. Two of the decorated sepulcral stones in the Kivik grave, and (below) the shore profile at $1000 \mathrm{BC}[6]$.

There are two quite clear omega-signs. Their origin must, of course, come from the Aegean region with older occurrences also in Egypt and Mesopotamia [1] [2] [3] [6] [12]. A third omega-sign occurs on a block included in the nearby monument known as Heimdall's Stones [3] [10]. In 2017, we think we identified one (or two) possible omega-signs on a block of Hagbards Galge (30 km northwest of Halmstad; Figure 3). 
At the top of the right stone in Figure 4, there is a war-chariot more or less identical to those used in Mycenae [3] [13] [14]. A similar picture of a war-chariot also occurs on the "Villfarar-stone", $18 \mathrm{~km}$ to the south (Figure 3), erected on the top of a grave containing a bronze object with spiral ornaments (Figure 5) with an estimated age of 1600 BC. The war-chariot is a sign of Indo-European [15]. Its appearance in southeast Sweden is indicative of active cultural exchange between Mycenaean Greece and southeast Sweden already in $1600-1700$ BC.

Pictures of huge ships started to appear frequently on rock-carvings and tool ornaments in Scandinavia all from the onset of the regional Bronze Age at 1750 BC [7] [16]. Those ships are so large and completely unknown from local ship building tradition that they must represent big ships used for open water travel (not ships for rivers demanding pulling and carrying at rapids and watersheds). They represent something new, suddenly appearing in the seas bordering our coasts, viz. at the Kattegatt-Skagerack Sea in the Tanum region in SW Sweden, and at the Baltic shore in the Ravlunda-Kivik area in SE Sweden.

Aegean travel and trading outside The Straits of Gibraltar already at 1750 BC opens new perspectives on long-distance travel and trading as further discussed in [3].

Some of the Swedish rock-carvings of ships are so similar to pictures found in Greece (Figure 6) that we may well term them "almost identical" [1] [3] [6].

"We have no doubts that the Aegeans and Phoenicians were true Atlantic Ocean sailors and, in their excellent ships, in the Bronze Age reached all the way up to Hyperborea, today's Scandinavia, in their search for amber, furs and maybe even tar" to quote our conclusion in 2010 [1].

\section{The Sun Cult}

It is common knowledge that the Sun played a central role during the Scandinavian Bronze Age [17] [18] [19]. This is evident from numerous solar symbols on
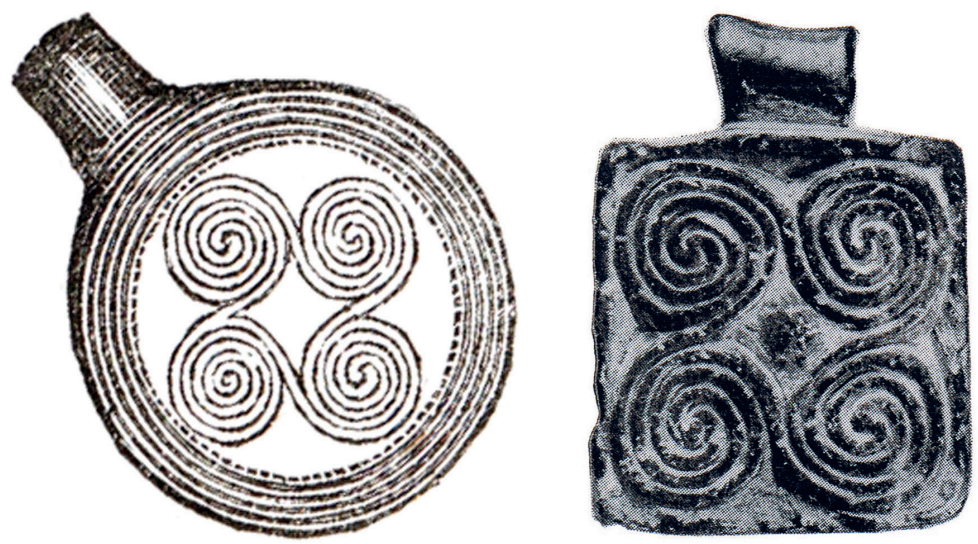

Figure 5. Spiral ornament from Sweden (left) and Greece (right). They are so similar, not to say identical, that a cultural interchange between the two regions seems already obvious at about 1600 - 1700 [3] [6]. 


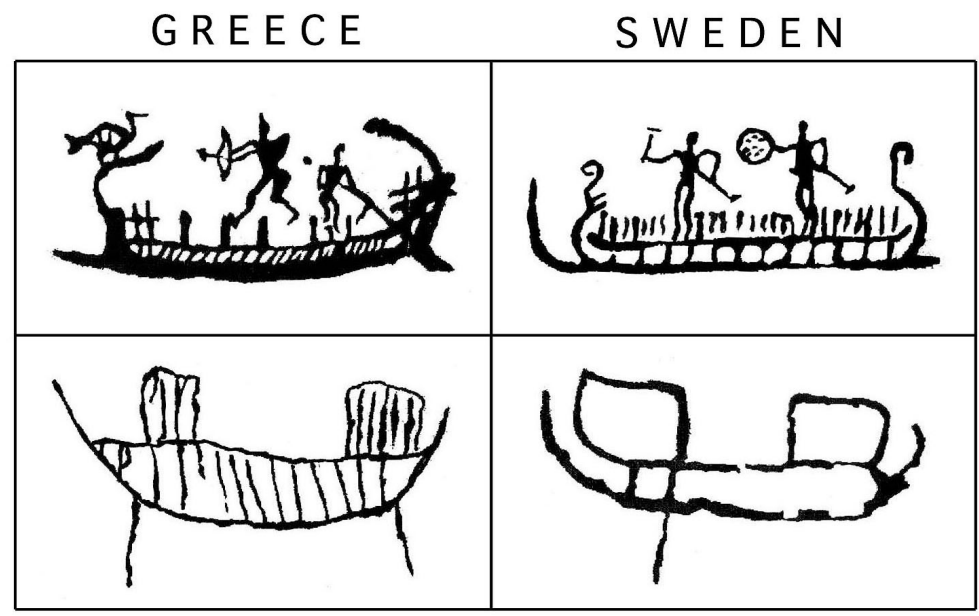

Figure 6. Pictures of ships found in Greece have almost identical analogues (natural as well as schematic ones) carved into the bedrock in southern Sweden (modified from [3]).

rock-carvings and bronze ornaments and objects.

The Sun chariot from Trundholm in Denmark is a vivid evidence of the presence of a Sun cult. It was found in a peat bog in 1902 [20]. In this paper we will expand on this Sun cult and present a re-interpretation of a remarkable object from SE Sweden, viz. the Golden Sky Dome from Mjövik.

\subsection{Solar Alignments of Rock-Carvings}

In the Simrishamn area of southeast Sweden (Figure 3), there are several bedrock surfaces covered by extensive rock-carvings. Many pictures have been affected by subsequent fracturing from an earthquake occurring $750 \mathrm{BC}$ [21] [22]. Consequently, the rock-carvings pre-date this event.

The most impressive site is at Järrestad where there are hundreds of pictures cut into a bedrock surface consisting of quartzite [23] [24].

The pictures occurring on the Järrestad site have been subjected to a statistical analysis of alignments [24]. A central image is the so-called "Dancer". $\mathrm{He}$, or more probably she, is facing the SE with her symmetry axis in $135^{\circ}$. This implies that she is waiting for the Sun to rise at the Winter solstice, and the onset of the days to become longer and brighter. On the same site, there are also cut 69 feet and 11 pairs of feet. The majority of those (60 out of 80 or $75 \%$ ) are pointing to the SE; i.e. the sunrise at Winter solstice. There are also 19 pairs of "shoes" and 45 single "shoes", 61 of which are pointing to the SE (i.e. 95.3\%).

This seems to provide clear indication that the Winter solstice played a central role in the life of Bronze Age people in SE Sweden. This, in its turn, confirms the importace the Sun played during the Bronze Age.

Other objects in the rock-carving have solar alignments, too. There are 20 ships. All of those are pointing to the SW; i.e. the sunset at Winter solstice. A serpent is aligned to the NW; i.e. the sunrise at Summer solstice (15\% of the feet have the same alignment). 
The vertical image of a small boat with 4 cup-marks [3] [6] [21] [22] [24] is aligned in NW-SE, just as the huge monument of Ales Stones is.

\subsection{Astronomical Sun Monuments}

Ales Stones (Figure 7) is a truly remarkable monument in southernmost Sweden. It is beautiful and impressive to observe. The ship is $67 \mathrm{~m}$ long and consists of 59 big blocks. The uniqueness and real significance lies in the construction of the stone ship (Figure 8). Lind recorded every sunrise and sunset over a full year as observed from the center of the ship. With this documentation, he was able to

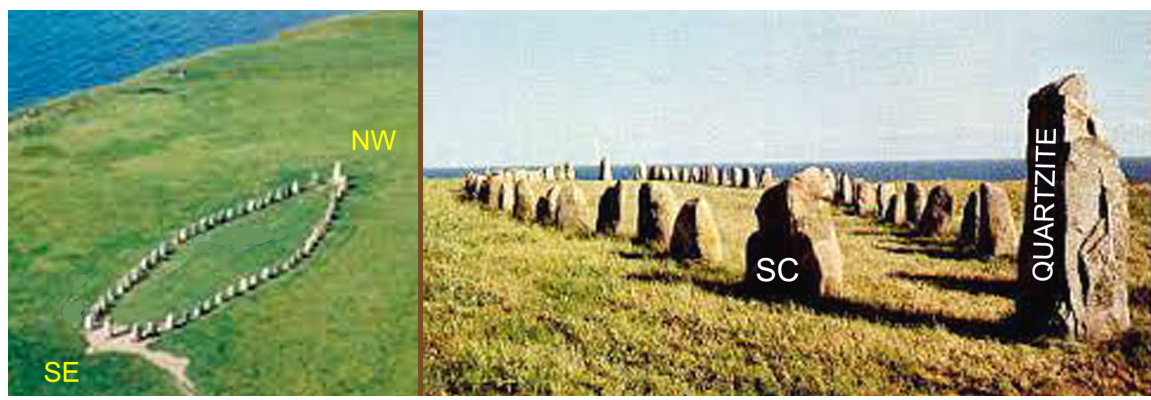

Figure 7. Ales Stones is a magnificent stone ship in southernmost Sweden $67 \mathrm{~m}$ long and built as an astronomical observatory to record the solar motions during the day and the year (modified from: [27]). Its symmetry axis of NW-SE is in perfect alignment with the sunrise at Winter solstice and sunset at Summer solstice. The bow and stern stones are gigantic megaliths of quartzite. The monument was erected in the late Bronze Age 750 BC. SC stands for cup marks forming the Cygnus (Swan) constellation.

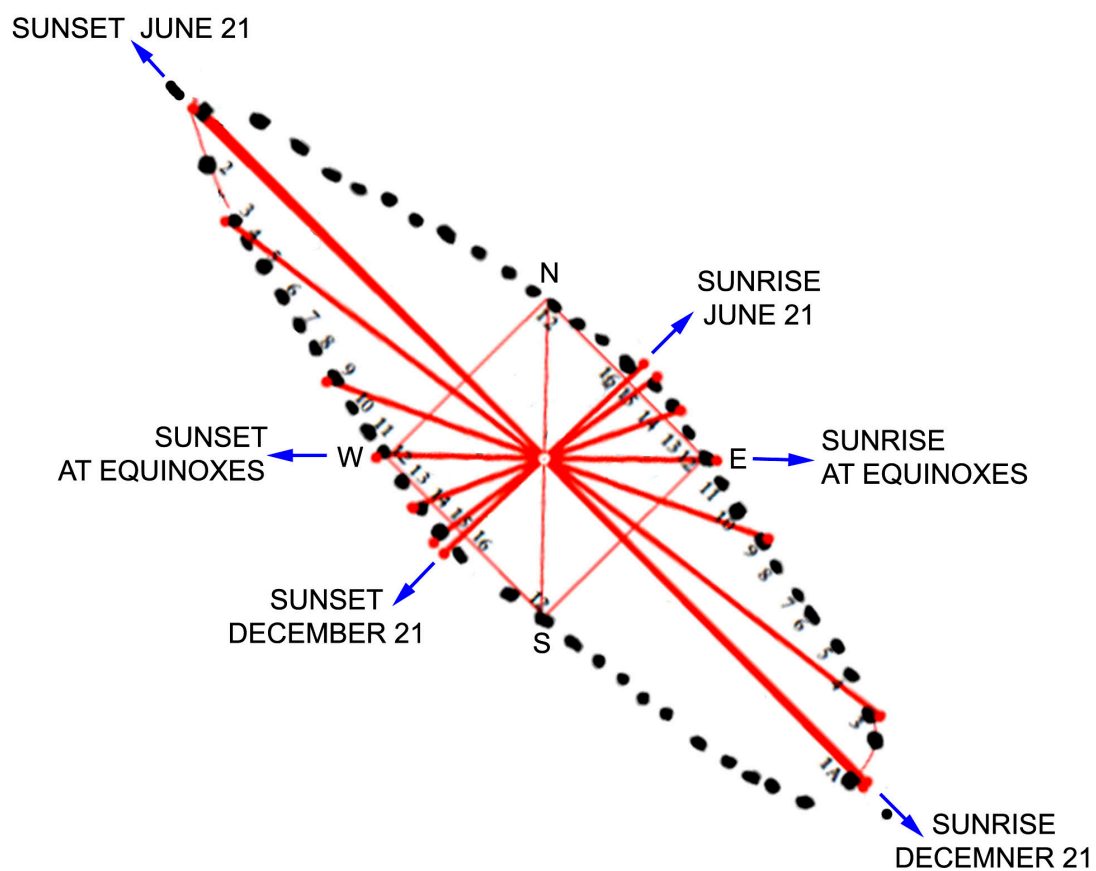

Figure 8. Ales Stones are built as an annual astronomical calendar of 365 days and 12 months (where the 7th was of 35 days, and all the others of 30 days; red lines) and a sundial of 16 one-and-a-half-hour long "hours" per day (based on [25]). 
show that the movements of the Sun over the year in relation to the blocks recorded 365 days and 12 months, where the 7th month was of 35 days and all the others of 30 days [25] [26]. It also worked as a sundial of 16 one-and-a-half-hour long intervals or "hours". This is, of course, truly remarkable.

On the top of the 8th block in the NW, there are 4 cup-marks in a boat form with the long-axis perfectly aligned to the sunrise at the Winter solstice and the sunset at the Summer solstice, and the short-axis aligned to the sunrise at Summer solstice and sunset at Winter solstice [6] [27].

On the top of the 8th block in the SE, there are 3 cup-marks in a triangle with the sight-line between two and straight over the third pointing exactly at sunrise at Winter solstice [6] [27].

On the 1st block to the east of the bow stone (Figure 7), there are 6 cup-marks in the form of the Cygnus (Swan) constellation [6].

Finally, we were able to show that Ales Stones are built after the same basic geometry-the rectangle, the circle and the Summer solstice alignment-as Stonehenge (Figure 9). This can, of course, not be a coincidence, but must be a manifestation that both monuments (though of different age) were built after the same basic principle [28].

This concludes the review of why Ales Stones were erected, and the answer is; as a sophisticated astronomical calendar.

Next question is: when was it erected [27]. We know that it must have been shortly after the earthquake dated at $780-750 \mathrm{BC}$ [21] [22] [27], but before the general sand drift dated at $600-500 \mathrm{BC}$ [27]. We also know that the huge monoliths of quartzite standing in the bow and stern of Ales Stones were quarried at Brantevik after the earthquake fracturing of the bedrock and transported by boat or raft to the shore at Kåseberga and then pulled up on the hill where they were

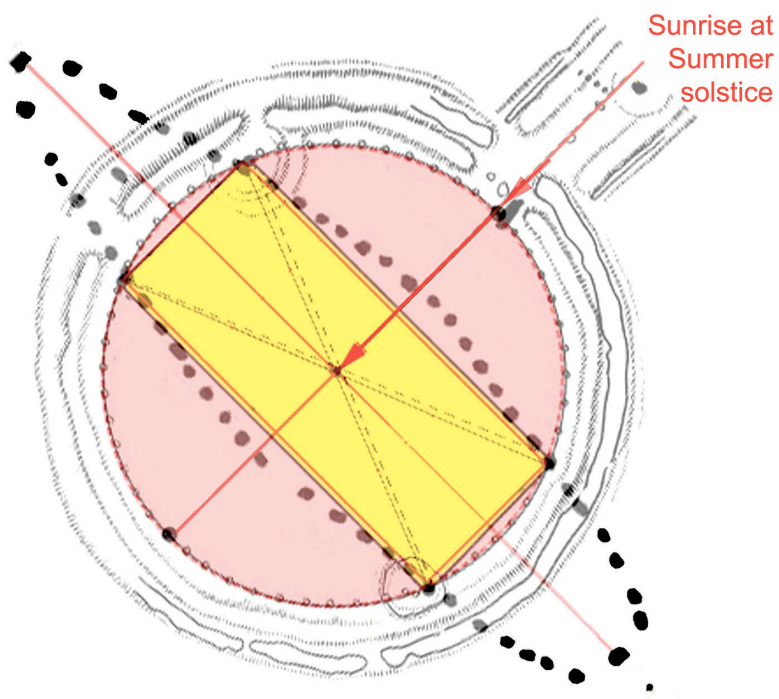

Figure 9. Superposition of Stonehenge (transparent) on top of Ales Stones (from [28]). The three basic geometric elements-the rectangle, the circle and the Summer solstice alignment in the two monuments-are almost identical. 
erected at about $750 \mathrm{BC}$ [21] [22] [27] [29]. This means that the stone ship was erected at the end of the Bronze Age.

Today, there is a minor deviation of $0.77^{\circ}$ of the sunrise at Winter solstice from the perfect straight alignment, which corresponds to an age of erection at about $700 \mathrm{BC}[6]$.

The agreement between the stratigraphic-radiocarbon age of $750 \mathrm{BC}$ and the deviation age of $700 \mathrm{BC}$ is satisfactorily close.

\subsubsection{Other Monuments in SE Sweden}

Stenhed is another stone ship oriented in SW-SE with respect to the sunset at the Summer solstice and the sunrise at the Winter solstice [6]. Its location is given in Figure 3.

Heimdall's Stones refer to a circular monument with strict alignments to the main Sun positions during the year. The sunrise at the Winter solstice has a panoramic direct sight-line to a distinct break-in-slope in the bedrock hill of Stenshuvud. Some of the stones have interesting rock-carvings (including one omega-sign). The site is described in great details in [10].

At Brantevik there are a number of graves from the Bronze Age. Even those graves show an orientation with respect to the Sun's annual motions [30]. From the southern grave, the Sun rises right over the northern grave ("Brantarör") at Summer solstice.

\subsubsection{Monuments in SW Sweden}

There are a number of monuments in the Båstad-Torekov area in SW Sweden (Figure 3) that are oriented with respect to the annual motions of the Sun over the sky (noted for the first time in [27]).

A huge Bronze Age grave known as "Dagshög" is bordered by two lines of stones, forming a $\mathrm{V}$-shaped figure. One of the lines is perfectly aligned to the sunset at Winter solstice and the point of the Kullen Peninsula to the SW.

To the north of Torekov, there is a group of Bronze Age graves built of beach shingle. A man-made passage leads out to them. The passage is aligned to the sunset at Summer solstice and the Sun sets right over the topmost grave. The passage must have been constructed to fit this alignment.

Tofta Högar refers to three Bronze Age graves, and a stone ship (9.2 m long and $2.7 \mathrm{~m}$ wide) aligned to the sunset at Summer solstice.

The Lungaro grave is a mound with a stone ship and grave inside. The ship is oriented E-W, i.e. in the solar directions at equinoxes, and with the grave at the middle of the south side of the stone ship.

It seems significant that the more we observe and measure of the geometry of Bronze Age monuments, the more objects with strict alignments to the solar motions we document.

\subsection{The Ancient View of the Sky and the Universe}

When a group of stars form a pattern or a picture, we speak about star constella- 
tions. Ancient people in Babylon, Egypt and Greece are known to have observed the sky and identified and named such constellations. In 1928, the International Astronomical Union (IAU) recognized 88 official modern star constellations.

The oldest picture of star constellations may be found on a Sumerian cylinder seal. Seal 47 in the Newell Collection [31] comes from the Diyala region northeast of Baghdad. It was assigned an age of about 4000 - 3200 BC, and it depicted a number of star constellations. According to [32], however, the motive was a depiction of the sky visible at a total solar eclipse in the year 3653 BC (September 12).

This means that people in the east had begun to identify and name star constellation already 2000 years before our Scandinavian Bronze Age. It seems, however, that the bulk of constellations were defined within a relatively short interval at around 1300 - 1000 BC [33], later to appear in the classical Greece constellations.

If the interpretation of the Ekenbergrock-carving of [32] [34] is correct (which surely seems to be the case), the Babylonian-Greece astronomical understanding and view of star constellations were already planted into the Swedish culture in the early Bronze Age.

Consequently, we can now establish 3 fundamental facts with respect to Swedish (Scandinavian) Bronze Age, viz.

1) The onset of our Bronze Age at $1750 \mathrm{BC}$ by travel and trading between the East Mediterranean region and SE Sweden (Figure 2).

2) The introduction of sophisticated solar astronomical knowledge as manifested in the circular calendar of Heimdall's Stones, numerous rock-carvings strictly oriented with respect to the annual solar motions and the remarkable solar calendar of Ales Stones (Figure 8).

3) The introduction of a Babylonian-Greece star constellation view as recorded in the Ekenbergrock-carving (Figure 10).

With this background, we will now analyze two objects (4 and 7, below) from the Bronze Age, and demonstrate that they can only be understood in terms of ancient astronomy (points 1 - 3 above).

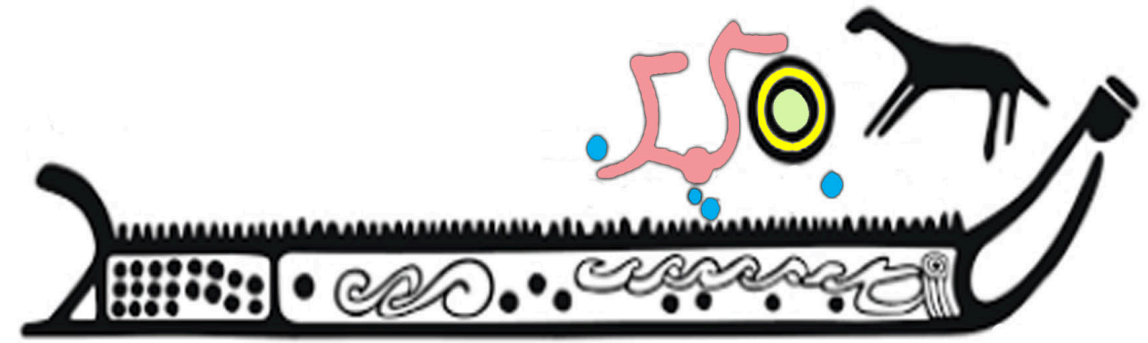

Figure 10. Rock-carving at Ekenberg (Norrköping, Sweden), identified by Henriksson [32] [34] as a sky view depicting the Corvus and Hydra constellations as the ship, the Leo constellation (pink), the Sun (yellow) at an eclipse in the year $1230 \mathrm{BC}$ and four planets (blue) (modified from [32] [34]). 


\subsection{The Golden Sky Dome from Mjövik (Nättraby)}

In 1847, a gold urn was found at Mjövik, Nättraby parish, in SE Sweden (Figure 3). The urn consists of leaf-thin gold with pressed ornamentation. It is $10 \mathrm{~cm}$ high. The urn was assigned an age of about 1000 BC. It is now kept in the "gold-room" of Statens Historiska Museum in Stockholm [35]. When we happened to see the form and ornamentation of the "urn", a completely new interpretation emerged; here presented for the first time.

From the side, the Mjövik golden urn may well be understood in terms of an urn or bowl (the bent edge suggests standing on a surface and contradicts a drinking bowl). Turned upside-down (Figure 11), however, a remarkable ornamentation is revealed: 12 solar symbols, 12 moons and a 6-spoke system.

In the center of the dome, there is a larger sun-symbol with 6 sunbeams or spokes connected with 6 of the 12 sun-symbols around the edge. This implies a base in the old Sumerian sexagesimal system (Figure 12). There are six spoke-bounded wedges, representing six 60-day intervals, which (together with the 5 - 6 additional leap year days) make a full solar year.

The first three 60-day segments include 2 sun-symbols and 2 moon-symbols. Segments 4 and 5 only include 1 moon per segment, however. The missing moons are present in the 6th segment, however, where 4 moons occur. Whether this is due to a simple mistake of the goldsmith or it has some deeper meaning is not yet known. However it is clear that we have here a manifestation of an elegant combination of the solar and lunar year by people worshiping the Sun in the Bronze Age.

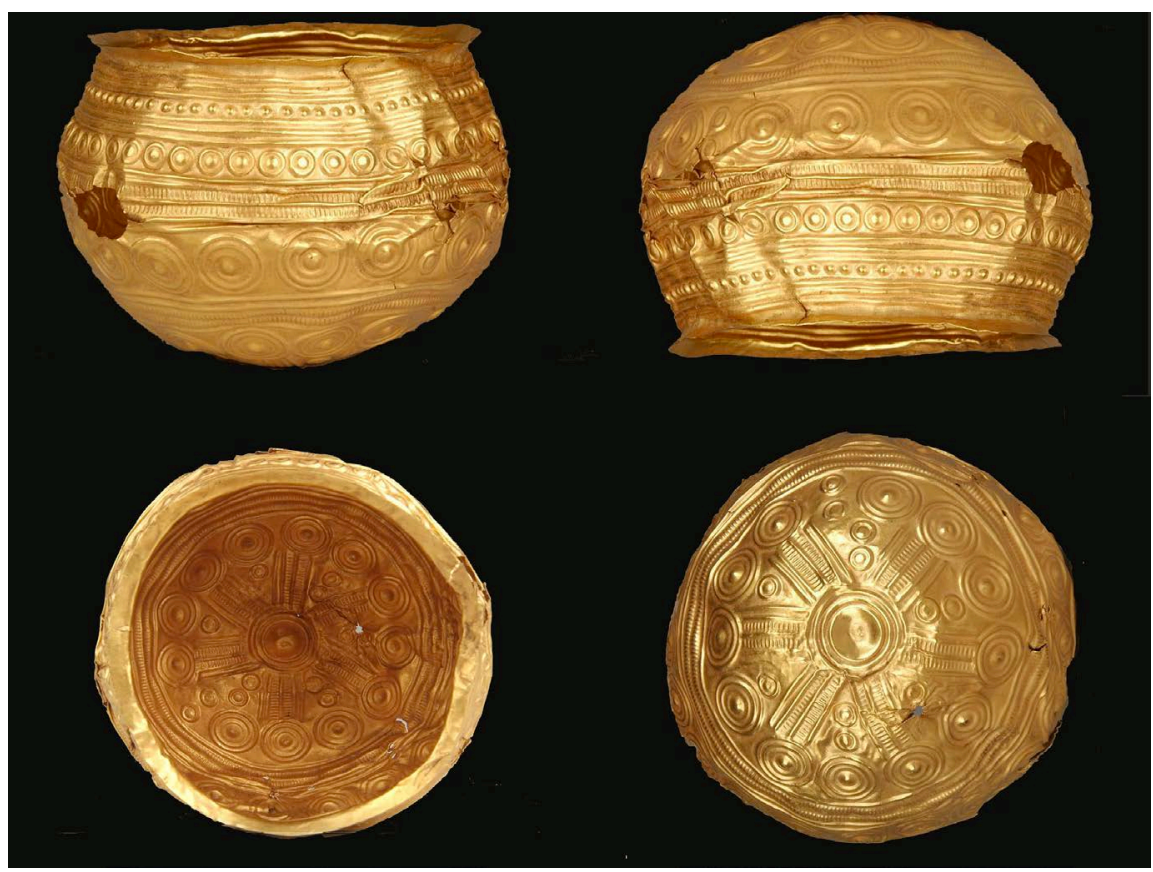

Figure 11. The golden urn from Mjövik (Nättraby) in 4 positions: as an urn or bowl, as a sky dome (i.e. upside-down with respect to general interpretation), looking down inside, and looking down on the sky dome from outside. 


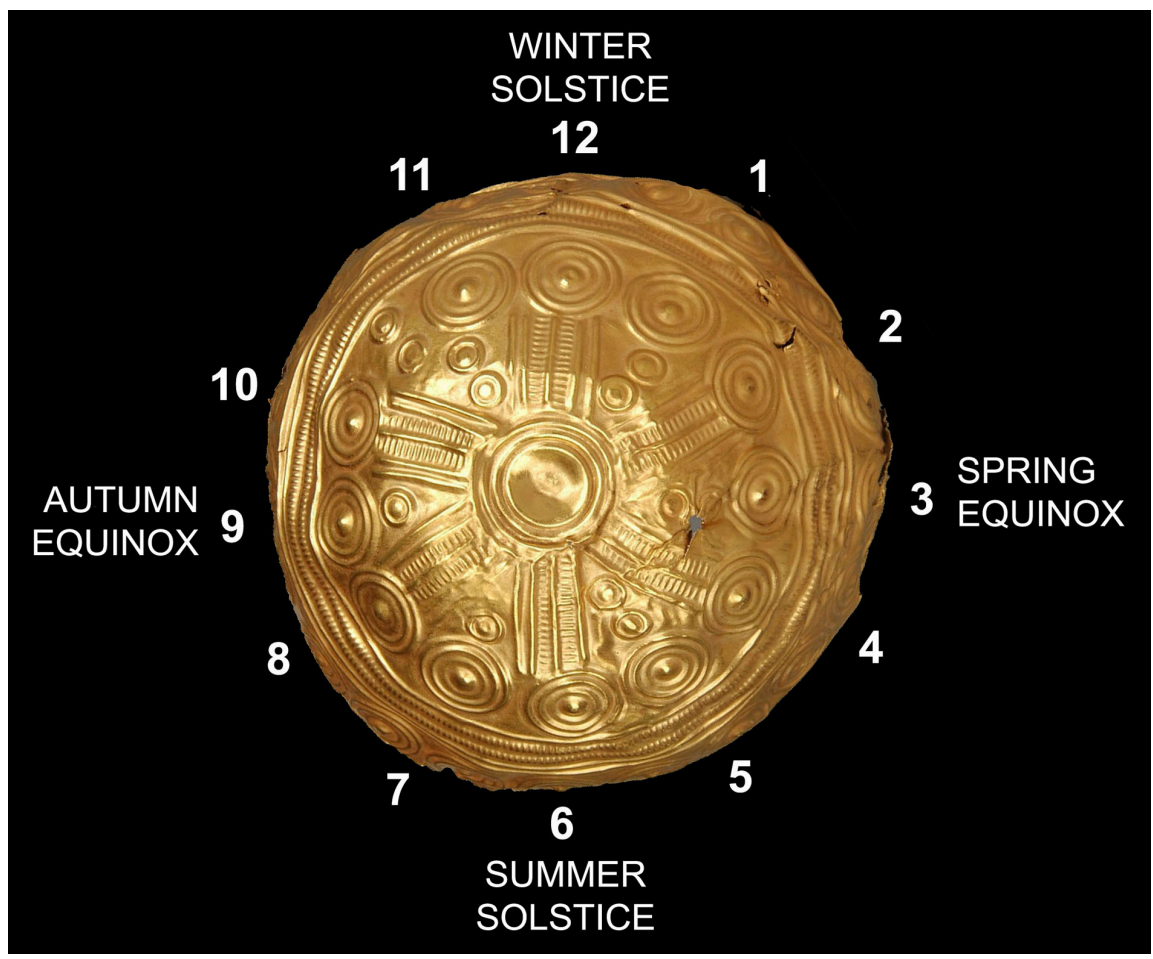

Figure 12. The golden urn from Mjövik turned upside-down into a solar sky dome or a 6-spoked sun wheel where there are six spoke-bounded wedge, representing six 60-day intervals-in accordance with the Babylonian sexagesimal system-which, together with the additional leap year days to be added in the sun-month June-July, makes a full year of 365 days

This implies that a new archaeoastronomical instrument has been found, recording the 12 solar-lunar months, and the motions of the Sun over the year (Figure 12).

From what has been presented above, we know that the Bronze Age people had an advanced knowledge in stellar astronomy (e.g. Figure 10) and in solar motions of the day and the year (e.g. Figure 8), and that the Sun cult was central in the Bronze Age (as stressed already by [17]).

Therefore, the right position of the golden object from Mjövik is here proposed to be with its dome-side upwards (right-hand-side images in Figure 11, and Figure 12) to record the solar-lunar annual motions as a sky dome or sun-wheel (Figure 12). At ritual occasions (like at the sunrise at the Winter solstice), it might, of course, have been used as drinking bowl, too.

\subsection{Rock-Carving with a 6-Spoke Sun and a Moon}

Rock-carvings from the Bronze Age are very abundant in Sweden. One of the favorite motifs is the Sun. We have searched for 6-spoked sun-wheels in Scandinavian rock-carving literature, and only been able to find one picture (Figure 13).

This picture shows the Sun and another celestial object (the Moon according to us but a comet according to an anonymous reviewer) when carried over the 


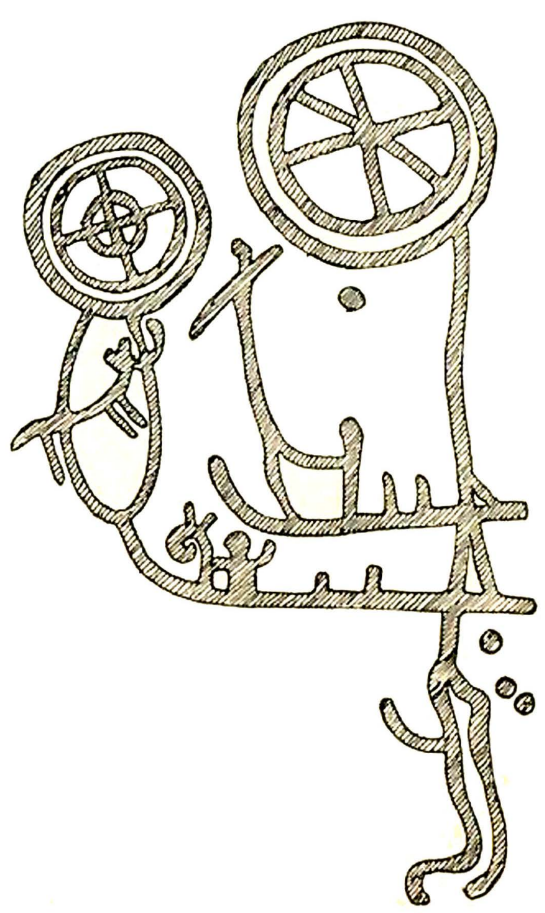

Figure 13. Rock-carving from the Bronze Age at Stora Backa, Brastad, Bohuslän in SW Sweden: A 6-spoked sun-wheel and a possible moon symbol. The Sun and Moon sympols are attached to two ships (sailing over the sky), which are held and controlled by a deity.

sky by two ships kept in motion by a deity. It provides an excellent image of the ancient solar-lunar observation and interpretation of the daily, monthly and annual motions over the sky.

\subsection{The Sun and the Moon Altars in Sippar, Babylonia}

Sippar was an important city in central Mesopotamia [36] [37] with a famous Sun temple. A stone tablet from this temple provides an image of two altars; one for the Moon and one for the Sun, with a high priest pointing at the Sun (Figure 14). The Sun symbol is a wheel with 6 spokes just as the sun-wheels on the Mjövik Golden Sky Dome (Figure 12) and in the rock-carving from Brastad (Figure 13). The 6-spoke sun-wheel is an illustration of the ancient Sumerian sexagesimal system. The sun-wheel is composed of 6 segments each of which represents 60 days, hence together making a full year of 360 days with the leap year days added in the sun-months June-July (just as recorded in the solar calendar of Ales Stones; Figure 8) giving 365 days.

The Sippar stone tablet has been assigned an age of about 1200 - 1300 BC [17] [18], but the tradition, mathematics and solar-lunar worshiping are much older. Obviously, it reached Scandinavia already in the Early Bronze Age.

\subsection{The "Ritual Object" from Balkåkraa}

In 1847, a bronze object was found in a peat bog at Balkåkra in southern-most Sweden (Figure 15). An identical object was found in northern Hungary (at 


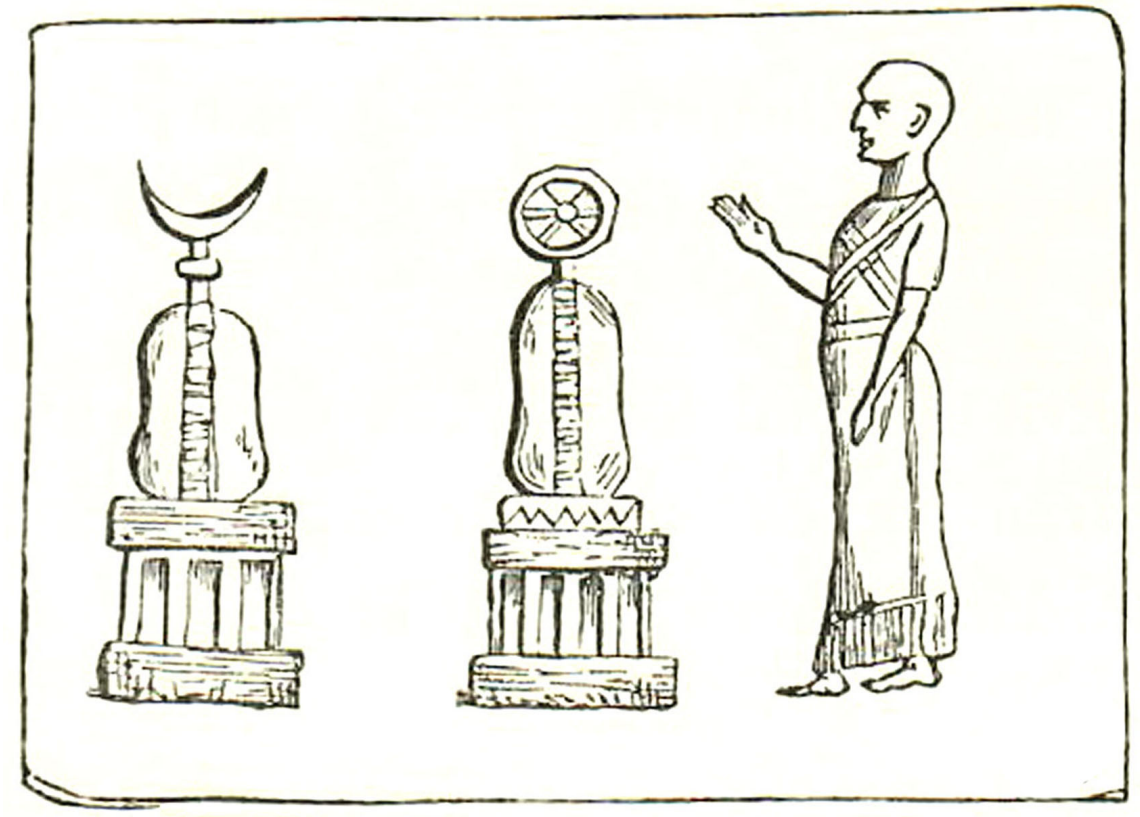

Figure 14. Stone tablet from the ancient Suntemple at Sippar, north of Babylon, from $1200-1300$ BC, showing the altars of the Sun and the Moon. The Sun is shown as a 6-spoke sun-wheel, which the high priest is pointing at (from [17]).

(a)
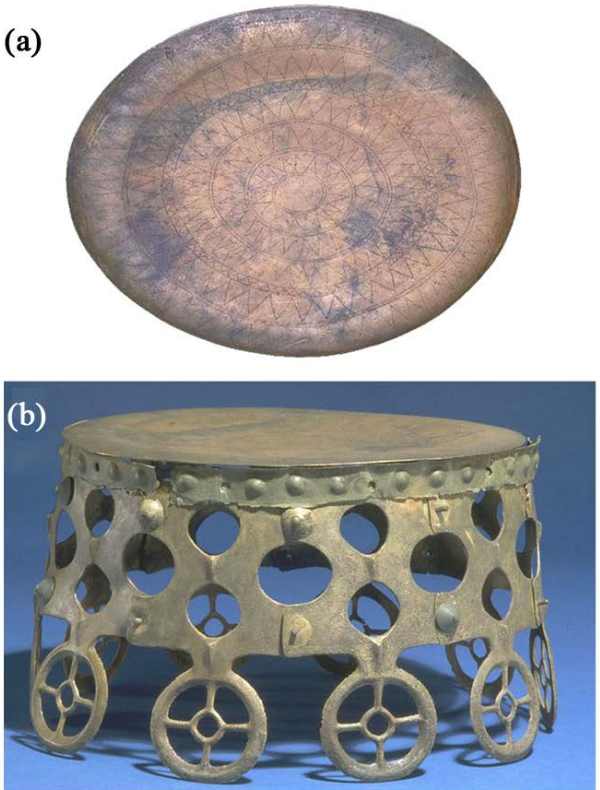

(c)

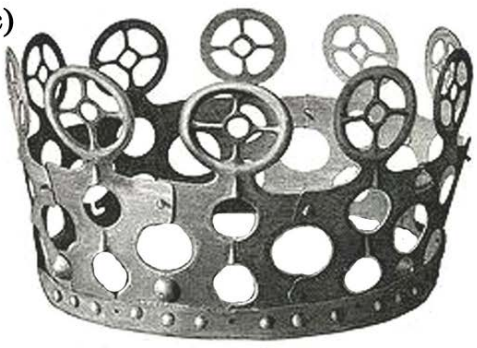

(d)

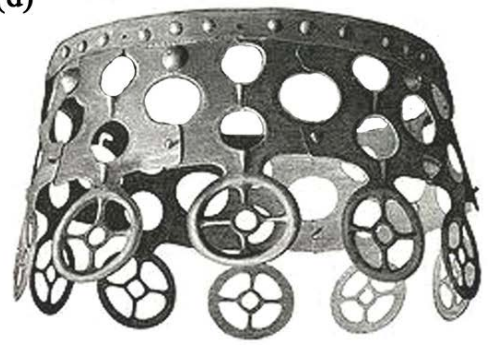

Figure 15. The Balkåkra Ritual Object. (a) Solar ornamentation on the flat surface; (b) view from the side; (c) and (d) alternalive positions. There are numerous different ways for sunbeams to shine through the holes and wheels and through marks in the bottom of the object (c) or at the ground below (d) marking motions of the Sun during the day and the year. We have not yet figured out exactly how this might have worked.

Hasfalva near Sopron) in 1913. The technique indicates that they were both manufactured by the same craftsman (or workshop). In Sweden it is assigned an age of $1500-1300 \mathrm{BC}$, and in Hungary an age of $1000-800$ BC. 
This "ritual object" was interpreted in many different ways; a drum, a sun altar, a gong or a throne [38]; even a "fire-mirror" has been proposed [39].

None of the proposed interpretations seem to hold up to deeper analyses. It seemed obvious that we are dealing with an object closely linked to the Sun cult: the surface has a typical solar ornamentation, and it stands on 10 solar wheels. We therefore propose that it is some sort of an astronomical clock or sundial. We have measured the angles at different solar positions, but not yet been able to figure out how it exactly may have worked.

\subsection{The Sun Chariot from Trundholm in Denmark}

The Sun Chariot from Trundholm was mentioned above. The idea that the sun disk is carried over the sky on a chariot pulled by a horse (Figure 16) is a perfect visualization of how people in the Bronze Age understood the Sun's motions over the sky during the day. It is a true manifestation of the Nordic Sun Cult (e.g. [17]). It originates from the early Bronze Age.

\subsection{The Nebra Sky Disk from Germany}

The Nebra Sky Disk is another famous object indicating a deep interest in astronomy and sky phenomena in northern Europe in the Bronze Age.

The Nebra Sky Disk (Figure 17) was found in 1999 by treasure hunters near the town of Nebra in the Ziegel Forest $180 \mathrm{~km} \mathrm{SW}$ of Berlin [40] [41]. It is dated at about $1600 \mathrm{BC}$, i.e. the earliest part of North European Bronze Age. It is $32 \mathrm{~cm}$ wide.

According to [40] "the sensation lies in the fact that Bronze Age people managed to harmonize the solar and lunar years", and the sky disc was "an astronomical clock".

It is included in this paper, because it provides another vivid example of quite advanced astronomical understanding already in the early Bronze Age.

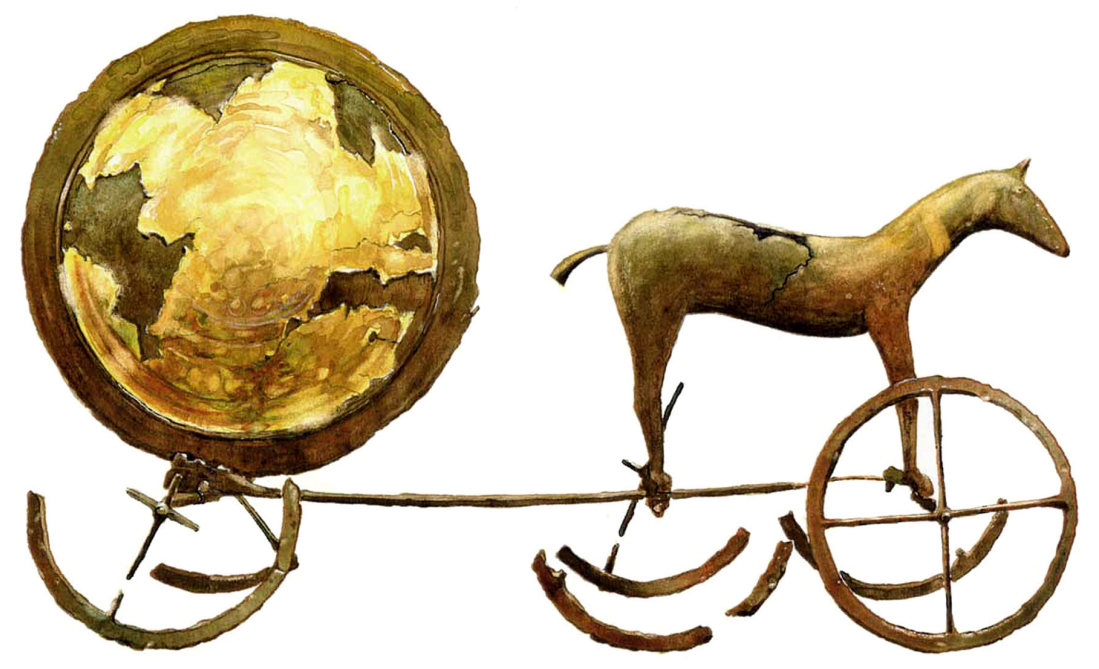

Figure 16. The sun chariot from Trundholm in Denmark. 


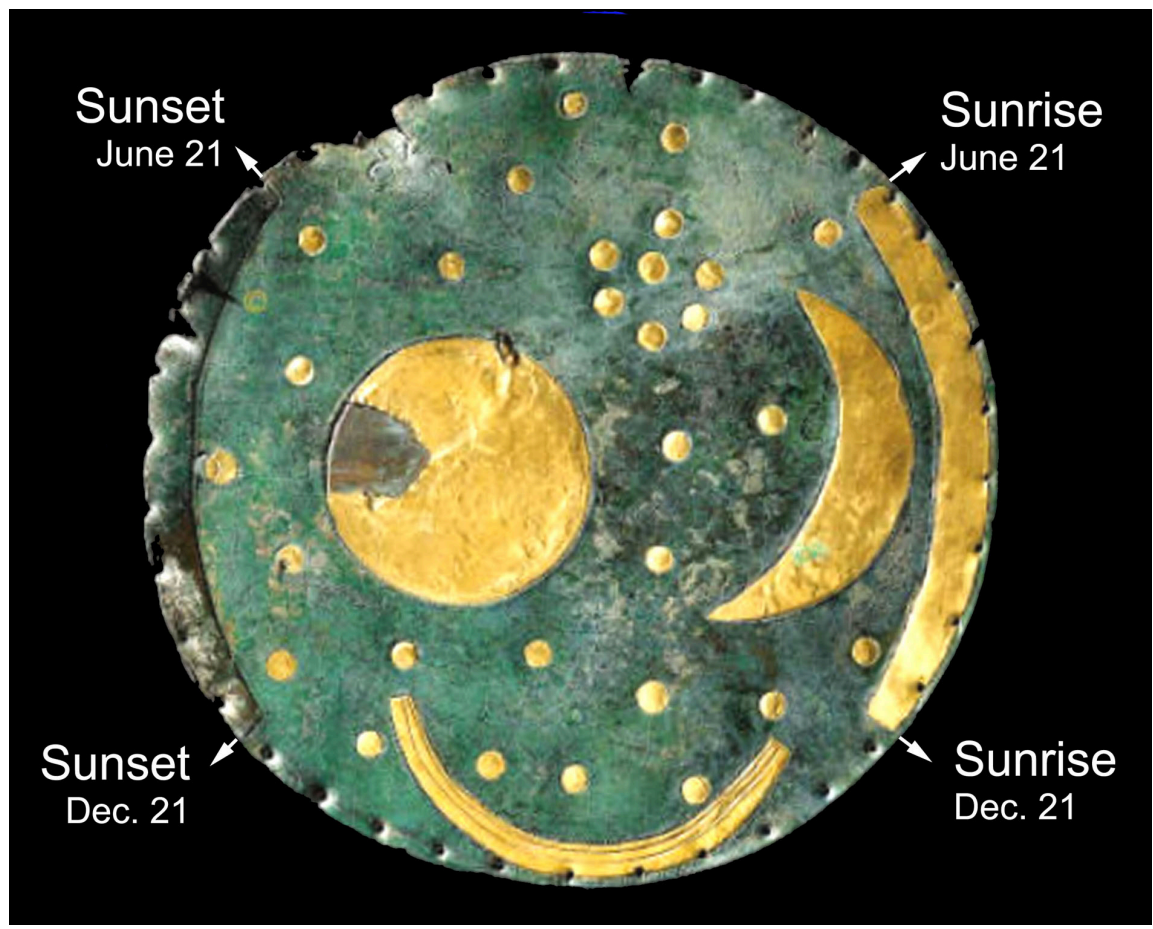

Figure 17. The Nebra Sky Disk was found in Germany and dated at about 1600 BC. Here with the geographical positions at sunrise and sunset at Summer solstice on June 21, and at the sunrise and sunset at Winter solstice on December 21 [42].

The annual solar motions proposed by [42] to be recorded in the Nebra Sky Disk (Figure 17) are the same as recorded with a much higher precision in the monument of Ales Stones (Figure 8).

\section{The Phallus Cult}

With onset of the Bronze Age, the Phallus cult rapidly spread over Scandinavia. This is most vividly seen in rock-carvings at different places all over Sweden, the most well-known example coming from Bohuslän in SW Sweden. The Phallus cult has clear roots in the eastern Mediterranean region.

Figure 18 shows a rock-carving of three excited warriors and their dogs from Fossum in Bohuslän as a good example of the Phallus cult during the Bronze Age. Fertility and rebirth are natural parts of the Phallus cult as illustrated in Figure 19.

\section{Perspectives and Conclusions}

Studies in southern Sweden [1] [2] [3] [6] [7] [9] seem to indicate that people from the Eastern Mediterranean region were real long-distance travellers, passing through The Strait of Gibraltar out over the open sea and reaching southern Sweden about $1750 \mathrm{BC}$, in this way initiating the beginning of the Bronze Age in Scandinavia (Figure 1).

Ancient harbours along the Portuguese coast are indicative of long-distance travel by eastern Mediterranean sailors [3] [43]. Furthermore, travels in the 


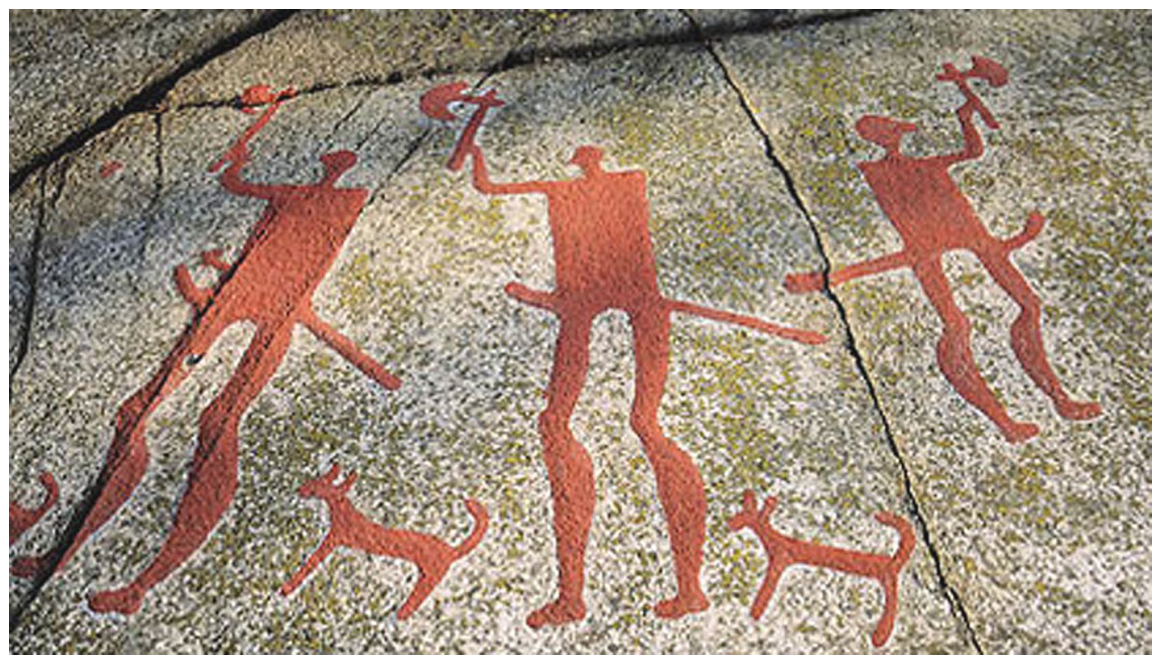

Figure 18. Rock-carving from the Bronze Age at Fossum in Bohuslän providing an example of the wide-spread Phallus cult in Scandinavian Bronze Age.

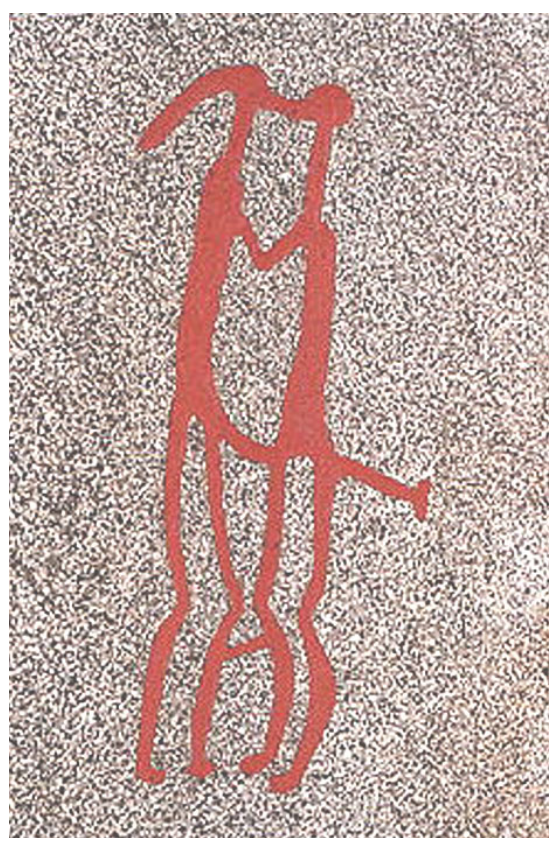

Figure 19. Rock-carving from Vitlycke in Bohuslän; fertility as part of Phallus cult.

Bronze Age all the way to the Azores are suggested by new observations [44] [45].

This supports the conclusion by [3]: "Reaching this far north by $1750 \mathrm{BC}$ in ships following the Atlantic coast of Europe implies that they as well may have reached much further south and west than previously assumed. This is where we open a door for extended analyses of long-distance travel and trading in the Bronze Age."

In conclusion, we trust we have shown that travel and trading in the Bronze Age was intensive and occurred over long distances. Cultural and trading influences from the Eastern Mediterranean and Middle East regions occurred partly 
over land and via rivers, and partly by huge ships over the open seas. The travel that sets the start of the Scandinavian Bronze Age must have been over the open seas, however (Figure 1 and Figure 2).

The ships images occurring as rock-carvings in Sweden must represent huge ships because they have a continuous log-keel extending forward in a pronounced battle-frame. Usually, the bow and stern are formed in the shape of impressive dragons. The ships seem to have been manned by a big crew (in a ship at Brastad, for example, one can count 36 persons). These ships must be built for open sea travels (as they are far to large and heavy for travel via river systems, which includes the pulling/pushing over land-bridges).

Very advanced understanding of astronomy and utilization of this knowledge in order to measure time of the year and time of the day seem to be firmly established in Northern European Bronze Age culture already at about 1750 BC (Figures 10-17); i.e. at the onset of the Bronze Age in Scandinavia and Northern Europe (Figure 1).

The Golden Sky Dome here presented in a new understanding includes the turning up-side-down of an assumed bowl (urn) so that it becomes a dome (Figure 11) with an intricate ornamentation representing the motions of the Sun and the Moon over the sky (Figure 12) and the merging of the solar months and the lunar months into a year of 360 days (6 times 60 days) plus an addition of leap year days in the Sun-months June-July (just as is the case in Ales Stones; Figure 8). This offers direct links to the Sumerian sexagesimal system and worshiping of the Sun and the Moon (Figure 14).

There can be no doubts that we in Swedish Bronze Age archaeology find not only evidence of long-distance travel and trading, but also deep cultural influences from Mesopotamia and the Eastern Mediterranean region (Figure 8, Figures 10-13 and, from Denmark and northern Germany, Figure 16, Figure 17).

\section{Acknowledgements}

We declare no conflict of interest. The paper was linguistically checked by Doctor Pamela Matlack-Klein, Appomattox, Virginia, USA. We acknowledge useful comments from two anonymous reviewers.

\section{References}

[1] Mörner, N.-A. and Lind, B.G. (2010) A Mediterranean Trading Centre in Southeast Sweden. In: Paraminopoulos, S.P., Ed., The Atlantis Hypothesis-Commentary, Heliotopos Publ., 685-699.

[2] Mörner, N.-A. and Lind, B.G. (2013) The Bronze Age in SE Sweden-Evidence of Long-Distance Travel and Advanced Sun Cult. Journal of Geography and Geology, 5, 78-91. https://doi.org/10.5539/jgg.v5n1p78

[3] Mörner, N.-A. and Lind, B.G. (2015) Long-Distance Travel and Trading in the Bronze Age: The East Mediterranean-Scandinavian Case. Archaeological Discovery, 3, 129-139. https://doi.org/10.4236/ad.2015.34012

[4] Penhallurick, R.D. (1986) Tin in Antiquity: Its Mining and Trade throughout the Ancient World with Particular Reference to Cornwall. The Institute of Metals, 
London.

[5] Haustein, M., Gillis, C. and Pernicka, E. (2010) Tinisotopy: A New Method for Solving Old Questions. Archeometry, 52, 816-832. https://doi.org/10.1111/j.1475-4754.2010.00515.x

[6] Lind, B.G. and Mörner, N.-A. (2010) Mykenska och Feniciska spår på Österlen. Stjärnljusets Förlag, Malmö.

[7] Mörner, N.-A. and Lind, B.G. (2008) A Mediterranean Bronze Age Trading Station in SE Sweden? 33rd IGC, Oslo, 6-14 August 2008, Symposium IEA-06.

[8] Ling, J., Hjärthner-Holdar, E., Grandin, L., Billström, K. and Persson, P. (2013) Moving Metals or Indinenous Mining? Provenancing Scandinavian Bronze Age Artefacts by Lead Isotopes and Trace Elements. Journal of Archeological Science, 40, 291-304. https://doi.org/10.1016/j.jas.2012.05.040

[9] Ling, J., Stos-Gale, Z., Grandin, L., Hjärthner-Holdar, E. and Persson, P.-O. (2014) Moving Metals II: Provenancing Scandinavian Bronze Age Artefacts. Journal of Archeological Science, 41, 106-132. https://doi.org/10.1016/j.jas.2013.07.018

[10] Mörner, N.-A., Lind, B.G. and Possnert, G. (2009) Heimdall's Stones at Vitemölla in SE Sweden and the Chronology and Stratigraphy of the Surroundings. Geografiska Annaler, 91A, 205-213. https://doi.org/10.1111/j.1468-0459.2009.00364.x

[11] Goldhahn, J. (2013) Bredarör på Kivik-En arkeologisk Odyssé. Simrishamn, Artes Liberales, 640 p.

[12] Nilsson, S. (1875) Spår efter fenisiska kolonier i Skandinavien. Svenska Fornminnesföreningens Tidskrift, 3, 1-39.

[13] Marstrander, S. (1963) Östfolds jordbruksristniger i Skeberg. Oslo.

[14] Kristensen, K. (2004) Långferderoghallristninger. Arkeologiska Skrifter, Göteborg.

[15] Beckwith, C.I. (2009) Empires of the Silk Road. Princeton.

[16] Ling, J. (2008) Elevated Rock Art. Towards a Maritime Understanding of Rock Art in Northern Bohuslän, Sweden. GOTARC Serie B, Gothenburg Archaeological Thesis, No. 49, 1-271.

[17] Montelius, O. (1911) Solguden och hans dyrkan. Nordisk Tidskrift, 1-26.

[18] Almgren, O. (1927) Hällristningar och kultbruk. Kungl. Vitterhets Historier Antikvitets Akademiens Handlingar, 35, 23-31.

[19] Bröndsted, J. (1938) Bronzealderens soldyrkelse. Gyldendal, København.

[20] Müller, S. (1903) Solvognen fra Trundholm. Nordiske Forntidsminder, 1, 6.

[21] Mörner, N.-A. (2012) Paleoseismic Fracturing of Rock Carvings 1000 BC in SE Sweden. INQUA-IGCP 567 Proceedings, 3, 127-130.

[22] Mörner, N.-A. (2014) An M > 6 Magnitude Earthquake 750 BC in SE Sweden. Open Journal of Earthquake Research, 3, 66-81. https://doi.org/10.4236/ojer.2014.32008

[23] Althin, C.A. (1945) Studium zu Bronxezeitlichen Felszeichnungen von Skåne. Gleerups, Lund.

[24] Mörner, N.-A. (2012b) Strict Solar Alignment of Bronze Age Rock Carvings in SE Sweden. Journal of Archaeological Science, 39, 3301-3305. https://doi.org/10.1016/j.jas.2012.05.027

[25] Lind, B.G. (2004) Ales stenar ur ett arekoastronomiskt perspektiv. Stjärnljusets Förlag.

[26] Lind, B.G. (2005) Ales stenar som solkalendarium. Ale, 4, 21-24. 
[27] Mörner, N.-A. (2015) Ales Stones in SE Sweden: A Solar Calendar from the Late Bronze Age. Journal of Archaeological Sciences: Reports, 2, 437-448. https://doi.org/10.1016/j.jasrep.2015.04.002

[28] Mörner, N.-A. and Lind, B.G. (2012) Stonehenge Has Got a Younger Sister. Ales Stones Decoded. International Journal of Astronomy and Astrophysics, 2, 23-27. https://doi.org/10.4236/ijaa.2012.21004

[29] Mörner, N.-A. (2017) Stenbrottet: Kvartsitblocken hämtades från Brantevik. Stjärnljusets Förlag, $16 \mathrm{p}$.

[30] Lind, B.G. (2011) Från Branta Rör till Brantevik. Stjärnljusets Förlag, 35 p.

[31] Von der Osten, H. (1934) Ancient Oriental Seals in the Collection of Mr. Edward T. Newell. Univeristy of Chicago Oriental Institute, Chicago, Vol. 22.

[32] Henriksson, G. (2017) The Acceleration of the Moon and the Universe-The Massof Gravitation. Advances in Astrophysics, 2, 184-196.

[33] Wiki (2017) Constellations. https://en.wikipedia.org/wiki/Constellation

[34] Henriksson, G. (1999) Prehistoric Constellation on Swedish Rock-Carvings. Actes Vème Conference, Gdansk, 5-8 September 1997, 155-173.

[35] SHM (Swedish Historical Museum) (2017) Objekt No 1426.

[36] Wiki (2017) Sippar. https://en.wikipedia.org/wiki/Sippar

[37] Rivkah, H. (1975) Ancient Sippar: A Demographic Study of an Old-Babylonian City, 1894-1595 BC. Nederlans Historisch-Archaeologish Instituut.

[38] SHM (Swedish Historical Museum) (2017) Balkåkra-A Ritual Object. https://www.flickr.com/photos/historiska/sets/72157624188349508/

[39] Freij, H. (1977) “Balkåkratrumman”-i solkultens tjänst? Fornvännen, 72, 129-134.

[40] Meller, H. (2002) Die Himmelsscheibe von Nebra-ein frühbronzezeitlicher Fund von außergewohnlicher Bedeutung. Archäeologie in Sachsen-Anhalt, 1, 7-23.

[41] Pernicka, E. and Wunderlich, C.-H. (2002) Naturwissenschaftliche Unter-suchungen an den Funden von Nebra. Archäologie in Sachsen-Anhalt, 1, 24-29.

[42] Boyes, R. (2002) Bronze Age Clock That Told Man It Was Spring. In: Welle, D., Ed., The Sky Disk of Nebra, Deutsche Welle, Bonn.

https://www.bibliotecapleyades.net/arqueologia/nebra_disk.htm

[43] Wachsmann, S., Dunn, R.K., Hale, J.R., Hohlfelder, R.L., Conyers, L.B., Erenwein, E.G., Sheets, P., PienheiroBlott, M.L., Castro, F. and Davis, D. (2009) The Palaeo Environmental Context of Three Possible Phoenician Anchorages in Portugal. The International Journal of Nautical Archaeology, 38, 221-253. https://doi.org/10.1111/j.1095-9270.2009.00224.x

[44] Rodrigues, A.F. (2015) Megalithic Constructions Discovered in the Azores. Archaeological Discoveries, 3, 51-61.

[45] Rodrigues, A.F., Martines, N.O., Ribeiro, N. and Joaquinito, A. (2015) Early Atlantic Navigation: Pre-Portuguese Presence in the Azores Islands. Archaeological Discoveries, 3, 104-113. https://doi.org/10.4236/ad.2015.33010 